\title{
Chronic constipation as a risk factor of urinary tract infection in children
}

\author{
Irna Fajri Syahny1, Mohammad Juffrie ${ }^{1}$, Pungky Ardany Kusuma1 \\ Departement of Pediatrics Faculty of Medicine Universitas Gadjah Mada, Yogyakarta, \\ Indonesia
}

\begin{abstract}
The prevalence of urinary tract infection (UTI) in children is still quite high. In Dr. Sardjito General Hospital, Yogyakarta the incidence of UTI is reported about $3.5 \%$. One of the risk factors of the incidence of UTI is chronic constipation. However, it is often not a concern in the management of UTI pediatric patients. The aim of the study was to evaluate the influence of chronic constipation in increasing the risk of UTI in children. This was an observational study with case-control design. Children with symptoms of UTI who visited at the Installation of Child Health, Dr. Sardjito General Hospital, Yogyakarta underwent dipstick urinalysis test and urine culture examination. Patients who showed positive urine culture was included in the case group, meanwhile patients who showed negative urine culture was included in the control group. All patients were then asked the history of the chronic constipation. The association between the constipation and the incident of UTI was evaluated using bivariate analysis continued by multivariate analysis. One hundred and twenty eight eligible subjects consisting 64 subjects in each group were involved in this study. Statistical analysis showed that children with chronic constipation have a 3.77 times higher risk of UTI $(O R=3.77 ; 95 \% \mathrm{Cl}=3.21-4.32$ ) compare to those without constipation. Furthermore, the chronic constipation remained to be independent risk factor of UTI. The incidence of UTI increased 3.99 times higher in children with constipation compare to those without constipation $(\mathrm{aOR}=3.99 ; 95 \% \mathrm{Cl}=1.028-15.48)$. In conclusion, chronic constipation has been proven to be a risk factor of UTI in children.
\end{abstract}

\section{ABSTRAK}

Prevalensi infeksi saluran kemih (ISK) pada anak masih cukup tinggi. Di Rumah Sakit Umum Pusat (RSUP) Dr. Sardjito, Yogyakarta insidensi ISK dilaporkan sekitar 3,5\%. Salah satu faktor terjadinya insidensi ISK adalah gangguan buang air besa (konstipasi) kronis. Namun demikian konstipasi sering kurang menjadi perhatian dalam tata laksan ISK pasien anak. Penelitian ini bertujuan untuk mengkaji pengaruh konstipasi kronis terhadap meningkatnya risiko ISK pada anak. Penelitian ini merupakan penelitian observasional dengan rancangan kasus-kontrol. Anak dengan keluahan ISK yang berkinjung ke Instalasi Kesehatan Anak, RSUP Dr. Sardjito, Yogyakarta menjalani tes urin dipstick dan pemeriksaan kultur urin. Pasien dengan kultur urin positif masuk dalam kelompok kasus sedangkan pasien dengan kultur urin negatif masuk dalam kelompok kontrol. Semua pasien selanjutnya ditanya tentang riwayat konstipasi kronis yang diderita. Hubungan antara konstipasi dan insidensi ISK dianalisis dengan uji bivariat dilanjutkan dengan multivariat. Seratus dua puluh delapan pasien yang memenuhi syarat terdiri dari 64 pasien untuk masing-masing kelompok terlibat dalam penelitian. Hasil uji statistik menunjukkan anak dengan konstipasi kronis mempunyai risiko 3,77 kali lebih tinggi menderita ISK $(\mathrm{OR}=3,77 ; 95 \% \mathrm{Cl}=3,21$ 4,32) dibandingkan dengan anak yang tidak menderita konstipasi. Selain itu, konstipasi kronik tetap menjadi faktor risiko terjadinya ISK. Insidensi ISK meningkat 3,99 kali lebih tinggi padak anak dengan konstipasi dibandingkan anak tanpa konstipasi $(\mathrm{aOR}=3,99 ; 95 \% \mathrm{Cl}=1,028-15,48)$. Dapat disimpulkan, konstipasi kronik terbukti merupakan faktor risiko ISK pada anak.

Keywords: urinary tract infection - chronic constipation - children - risk factor - incidency

\footnotetext{
* corresponding author: irnafajri@yahoo.com
} 


\section{INTRODUCTION}

Urinary tract infections (UTIs) is a relatively common infection in infants and young children. The UTIs remain become a health problem in children. They may result in significant acute morbidity and longterm medical complication. Without adequate treatment UTIs will cause vesico ureteral reflux as a result of urinary tract obstuction to renal scar. ${ }^{1-3}$ The incidence of UTIs is difficult to exactly assess because UTIs are not reportable diseseases. UTI in children accounted for $0.7 \%$ of physician office visits and 5-14\% of emergency department visits by children annually. ${ }^{1}$ The overall prevalence of UTI was $7.0 \%$ among infants presenting with fever. Whereas the incidence of UTIs was about $4 \%$ in both male and female infants during the first year. Female infants with fever had a relatively high prevalence rate of UTI, especially during the first year of life. ${ }^{3-5}$

Constipation has been reported to one of risk factors of UTI. Previous studies reported that $3.7-4.2 \%$ of children with chronic constipation sufferred from UTI. ${ }^{6-8}$ Constipation is the reason for approximately $3 \%$ of parents bringing children to the pediatricians and $25 \%$ are handled by a pediatric gastroenterologist. ${ }^{9}$ The prevalence of constipation in children is about $0.7-29.6 \% .{ }^{10,11}$ In United State primary care clinic, the prevalence rates of constipation are $22.6 \%{ }^{6}$

Constipation may cause stretching of the rectum and pressure the bladder leads to the decrease of bladder's emptying process due to the instability of detrussor muscles and discoordination between detrussor contraction and external urethral sphincter relaxation. This leads to increase bladder pressure and residual volume in the bladder and gives the opportunity for bacteria to grow and cause UTI. ${ }^{12,13}$ The discoordination is found in $53 \%$ of children with constipation. $^{6}$
Although, constipation is the reason for about $3 \%$ of parents bringing their children to the pediatricians, however only $25 \%$ of them are handled by a pediatric gastroenterologist. In addition, constipation is often not a concern in the management of UTI pediatric patients. This study was conducted to evaluate the influence of chronic constipation on the incidence of UTI among children visiting at the Installation of Child Health, Dr. Sardjito General Hospital, Yogyakarta.

\section{MATERIALS AND METHODS}

\section{Subjects}

This study was an observational study using used a case-control design performed at the Installation of Child Health, Dr. Sardjito General Hospital, Yogyakarta commencing March 2009 until March 2010 with the aim of evaluating the role of chronic constipation in increasing the risk of UTI in children. The case group was the children who suffered UTI, while the control group was those not suffered UTI. Inclusion criteria of this study were children aged 2-18 years with clinical UTI for the case group and without UTI for the control group, not use antibiotics in the last 48 hours before the examination of urine culture, their parents had agreed that their children participated in this study after getting information and signing the inform consent. Patients were excluded if they had a history of neurological or anatomical abnormalities, immunocompromise patients (patients with HIV infections, cancer, having corticosteroids or other immunosupressant drugs) and used of transurethral catheterization. The sample size in this study was calculated using the formula test of the hypothesis of an odds ratio $(\mathrm{OR})$ with á value of 0.05 and â value of 0.20 . The number sample of each case and control groups was 64 patients. 


\section{Procedures of the study}

Children with symptoms of UTI who visited at the Installation of Child Health, Dr. Sardjito General Hospital, Yogyakarta underwent dipstick urinalysis test in less than 30 minutes after urine sampling and urine culture examination. Patients who showed positive urine culture was included in the case group, meanwhile patients who showed negative urine culture was included in the control group. Patient suspecting of having a UTI if the number of bacterial count on urine culture was e" $10^{5}$ coloni forming unit $/ \mathrm{mL}$ (CFU/mL) using the urine sample obtained from midstream urine; or e" $10^{4} \mathrm{CFU} / \mathrm{mL}$ from trancatheter urine, and one or more bacteria in the urine sample obtained from suprapubic puncture. Patients was considered to have not UTI if no white blood cells in the urine that evaluated with the urinary leucocyte esterase (LE) and nitrite tests. The urinary LE and or nitrite tests were considered to be negative if no color change in the urine dipstick was observed.

All patients were then asked the history of the chronic constipation. The criteria of chronic constipation were evaluated according to Rome III Diagnostic Criteria for Functional Gastrointestinal Disorders. The criteria for children under four years old was defecation less than three times a week or having pain during defacation and feces retention suffered if defecation more than three times a week. The criteria for children more than four years old if two or more following criteria was oberved i.e. a) defecation less than two times without laxantia; b) the existence of soiling or encopresis more than two times a week; c) defecation in a large volume every 7-30 days; d) the existence of palpable mass in the abdomen or rectum in physical examination.

\section{Statistical analysis}

Data were presented as mean \pm standard deviation (SD) or percent and then analyzed using a computer statistics program. Differences in the characteristics of the data were analyzed using chi square $\left(\mathrm{x}^{2}\right)$ for nominal data and t-test for numerical data. Bivariate analysis was conducted to assess the magnitude of the influence of risk factors for the occurrence of UTI by calculating the odds ratio (OR) values with $95 \%$ confidence interval. Multivariate analysis using logistic regression test was used to analyze the magnitude of the effect of risk factors by considering other risk factors on the incidence of UTI. This study had been approved by the Medical and Health Research Ethics Committee, Faculty of Medicine, Universitas Gadjah Mada, Yogyakarta.

\section{RESULTS}

One hundred and twenty eight eligible subjects consisting 64 subjects in each group were involved in this study. The characteristics of subjects are presented in TABLE 1. No significant different in characteristics of subjects includes age, gender and history of circumsision was observed between the two groups ( $p>0.05)$, except chronic constipation $(\mathrm{p}<0.05)$.

TABLE 1. Characteristics of subjects involved in the study

\begin{tabular}{lccc}
\hline Characteristics & UTT $(+)$ & UTI (-) & p \\
\hline$\Lambda$ ge (mean \pm SD year) & $8.2 \pm 4.6$ & $7.4 \pm 4.1$ & 0.327 \\
Sex & $41(64 \%)$ & $34(53 \%)$ & \\
• Girl & $23(36 \%)$ & $30(47 \%)$ & 0.209 \\
• Boys & & & \\
Chronic constipation & $10(16 \%)$ & $3(5 \%)$ & 0.041 \\
• Yes & $54(84 \%)$ & $61(95 \%)$ & 0.288 \\
- No & $1(5 \%)$ & $4(13 \%)$ & 0. \\
History of circumcision (boys) & & & \\
\hline
\end{tabular}


Statistical analysis of the influence of risk factors to the incidence of UTI is presented in TABLE 2. It was found in this study that children with chronic constipation have a 3.77 times higher risk of UTI $(\mathrm{OR}=3.77 ; 95 \% \mathrm{CI}=3.21$ 4.32) compare to those without constipation. In addition, the chronic constipation remained to be independent risk factor of UTI. The incidence of UTI increased 3.99 times higher in children with constipation compare to those without constipation $(\mathrm{aOR}=3.99 ; 95 \% \mathrm{CI}=1.028$ 15.48).

TABLE 2. Statistical analysis the correlation between chronic constipation and other risk factors and the incidence of UTI

\begin{tabular}{lcc}
\hline Risk factors & OR $(95 \% \mathrm{CI})$ & aOR $(95 \% \mathrm{CI})$ \\
\hline - Chronic constipation & $3.77(3.21-4.32)$ & $3.99(1.028-15.48)$ \\
- Sex & $1.57(1.41-1.74)$ & $0.645(2.309-1.347)$ \\
- Age & $1.48(1.33-1.62)$ & $0.966(0.890-1.048)$ \\
\hline
\end{tabular}

\section{DISCUSSION}

Age has been associated with the prevalenve of UTI, beside gender, race and circumcision status. ${ }^{4}$ This study found that the incidence of UTI was higher in girls than boys among the school-age children (the overage age of $8.2 \pm 4.6$ years) involved in this research. This result was consistent with previous study that reported that the prevalence of UTI in girls was higher (1-11\%) than in boys (2-4\%). ${ }^{11,14}$

It was also reported that in the incedence of UTI in female children with chronic constipation $(33 \%)$ was higher than those in male children (3\%). ${ }^{6}$ Moreover, Lumbanbatu et al. ${ }^{15}$ reported that the prevalence of UTI in girls $(7.0 \%)$ was higher than in boys $(1.0 \%)$ in school-aged children. Other previous study supported that girls had an higher risk of UTI than boys in the children. ${ }^{16-18}$ The higher prevalence of UTI in girls compared to boys is related to the anatomy of female urinary tract system. A short urethra of girls, in comparison with boys, has been proposed as being a factor in facilitating spread of ascending infection. Small urethral diameter in grils has also been cited as a reason for susceptibility of some girls to UTI. ${ }^{19}$ In addition, bacteria may also be introduced into a girl's bladder by wiping from back to front after a bowel movement, which can contaminate the urethral opening. It may also increase the risk of getting a UTI. ${ }^{20}$

This study found that children with chronic constipation have higher risk of UTI compare to those without constipation. Moreover, the chronic constipation remained to be independent risk factor of UTI. This result is in accordance with previous studies that reported that constipation was one of risk factors of UTI in children. ${ }^{6-8}$ The possibility of pathogensis of UTI due to constipation has been postulated. Constipation causes stretching of the rectum and pressure the bladder which cause the decrease of bladder's emptying process due to the instability of detrussor muscles and discoordination between detrussor contraction and external urethral sphincter relaxation. This leads to increase bladder pressure and residual volume in the bladder and gives the opportunity for bacteria to grow and cause the infection. ${ }^{12,13}$

The most common bacteria observed on urine culture in this study were Escherichia coli (35.9\%), Pseudomonas aeruginosa (20.3\%), and coagulase negative Staphylococcus $(14.1 \%)$. Many other studies also reported that 
E. coli was the most frequent bacteria isolated from children with UTI. ${ }^{21-24}$ However, Muoneke et $a l .{ }^{25}$ reported that Klebsiella was the commonest bacteria found from children with UTI followed by $S$. aureus. The difference of bacterial pathogens of UTI may be influenced by the bacterial pattern in an area. As reported in previous study that epidemiology and bacterial pathogens in children with UTI showed large inter-regional and rates of bacterial resistance variability. ${ }^{26}$

\section{CONCLUSION}

In conclusion, chronic constipation has been proven as a risk factor of UTI in children. Concern should be addressed by clinicians on children with constipation in order to improve the management of UTI pediatric patients.

\section{ACKNOWLEDGEMENTS}

The high appreciation should be provide to the subjects and their parents who have participated in this study. This study became possible with the permission from Head of Department of Pediatrics Dr. Sardjito General Hospital/Faculty of Medicine, Universitas Gadjah Mada, Yogyakarta.

\section{REFFERENCES}

1. Freedman AL. Urologic diseases in North America Project: trends in resource utilization for urinary tract infections in children. J Urol 2005; 173(3): 949-54.

2. Holland NH, Jackson EC, Kazee M, Conrad GR, Ryo UY. Relation of urinary tract infection and vesicoureteral reflux to scars: follow-up of thirtyeight patients. J Pediatr 1990; 116(5): 65-71.

3. Ma JF and Shortliffe LM. Urinary tract infection in children: etiology and epidemiology. Urol Clin North Am 2004; 31(3): 517-26.

4. Shaikh N, Morone NE, Bost JE, Farrell MH. Prevalence of urinary tract infection in childhood: a meta-analysis. Pediatr Infect Dis J 2008; 27(4): 302-8.
5. Foxman B. Epidemiology of urinary tract infections: incidence, morbidity, and economic costs. Dis Mon 2003; 49(2): 53-70.

6. Loening-Baucke V. Urinary incontinence and urinary tract infection and their resolution with treatment of chronic constipation of childhood. Pediatrics 1997; 100(2 pt 1): 228-32.

7. Keuzenkamp-Jansen CW, Fijnvandraat CJ, Kneepkens CM, Douwes AC. Diagnostic dilemmas and results of treatment for chronic constipation. Arch Dis Child 1996; 75(1): 36-41.

8. Kasirga E, Akil I, Yilmaz O, Polat M, Gözmen S, Egemen A. Evaluation of voiding dysfunctions in children with chronic functional constipation. The Turk J Pediatr 2006; 48(4): 340-43.

9. van den Berg MM, Benninga MA, Di Lorenzo C. Epidemiology of childhood constipation: a systematic review. Am J Gastroenterol 2006; 101(10): 2401-9.

10. Loening-Baucke V. Prevalence rates for constipation and faecal and urinary incontinence. Arch Dis Child 2007; 92(6): 486-9.

11. Adams GR, Ball CS, Corwin RM, Fuquay D, Harley BM, Heimerl MJ, et al. Practice parameter: the diagnosis, treatment, and evaluation of the initial urinary tract infection in febrile infants and young children. Pediatrics 1999; 103(4): 843-52.

12. Gonzales ET, Roth DR. Urinary tract infection: Oski's essential pediatric $2^{\text {nd }}$ ed. Editor: Crocetti M, Barone MA. Philadelphia: Lippincott Williams \& Wilkins. 2004; 486-7.

13. Gonzales ET, Roth DR. Urinary tract infection. In: Oski's pediatrics: Principles and practice. $4^{\text {th }}$ Edition. Editor : McMillan JA, Deangelis CD, Feigin RD. Philadelphia: Lippincott Williams \& Wilkins. 2006; 1837-41.

14. Larcombe J. Urinary tract infection in children. BMJ 1999; 319(7218): 1173-5.

15. Lumbanbatu SM, Rusdidjas, Ramayati R, Tobing R. Bakteriuria asimtomatik pada anak Sekolah Dasar laki-laki dan perempuan usia 9-12 tahun. Sari Pediatri 2001; 3(2): $67-71$.

16. Chang SL, Shortliffe LD. Pediatric urinary tract infection. Pediatr Clin N Am 2006; 53(3):379400 .

17. Alatas H. Hot topics in pediatrics II. Dalam: Pendidikan kedokteran berkelanjutan. Ilmu Kesehatan Anak XIV. Jakarta: Fakultas Kedokteran Universitas Indonesia. 2000; 15. 
18. Kennedy T. Urinary tract infection. In: Rudolph's pediatrics $21^{\text {st }}$ ed. Editor: Rudolph AM, Rudolph CD, Hostetter MK, Lister J, Siegel NJ editors. New York: The McGraw-Hill Company. 2002; 1997-2073.

19. Jantausch B and Kher K. Unirary tract infection. In: Kher K, Schnaper HW, Makker SP editors. Clinical pediatric nephrology $2^{\text {nd }}$ ed. New York: The McGraw-Hill Health, 2007; 553-71.

20. Rushton HG. Urinary tract infections in children: epidemiology, evaluation, and management. Pediatr Clin North Am 1997; 44(5): 1133-69.

21. Chang SL, Shortliffe LD. Pediatric urinary tract infections. Pediatr Clin N Am 2006; 53(3): 379400.

22. Cheng CH, Tsai MH, Huang YC, Su LH, Tsau YK, Lin CJ, et al. Antibiotic resistance patterns of community-acquired urinary tract infections in children with vesicoureteral reflux receiving prophylactic antibiotic therapy. Pediatrics 2008; 122(6): 1212-7.

23. Honkinen O, Lehtonen OP, Ruuskanen O, Huovinen P, Mertsola J. Cohort study of bacterial species causing urinary tract infection and urinary tract abnormalities in children. BMJ 1999; 318 (7186): 770-1.

24. Fong KW, Wong SN. Symptomatic urinary tract infection in children: experience in a regional hospital in Hongkong. HK J Paediatr (new series) 2004; 9: 30-6.

25. Muoneke VU, Ibekwe MU, Ibekwe RC. Childhood urinary tract infection in Abakaliki: etiological organisms and antibiotic sensitivity pattern. Ann Med Health Sci 2012; 2(1): 29-32.

26. Chakupurakal R, Ahmed M, Sobithadevi DN, Chinnappan S, Reynolds T. Urinary tract pathogens and resistance pattern. J Clin Pathol 2010; 63(7): 652-4. 